\title{
Correlation of Breastfeeding and Parenting with Early Childhood's Emotional Development
}

\author{
Nurhamidi $^{1{ }^{* *}}$ and Rizky Rindu Bajuri ${ }^{2)}$ \\ 1) Department of Nutrition, Politeknik Kesehatan Kemenkes Banjarmasin \\ 2) Alumni of the D-IV Nutrition, Banjarmasin \\ E-mail: nurhamidi1122@ gmail.com ${ }^{1 *}$ \\ albajurisky198@gmail.com²)
}

\begin{abstract}
The mental-emotional development children's is the interaction process of the maturation of the child's physiology and psychological organs to process and control emotions. Objectives: The study aimed to found out the correlation between exclusive breastfeeding and parenting with the mental-emotional development of early childhood in the working area of Puskesmas Guntung Manggis in 2021. Methods: The study is an observational analytic study with a cross sectional design. The sample of the study was 92 samples of early age (3-6 years) in the working area of Puskesmas Guntung Manggis, it was determined by a simple random sampling technique. The data analysis was conducted by the Rank Spearman correlation. Results: Based on the results shows that there is a relationship between exclusive breastfeeding with $\rho$ value (0.0)] and parenting with $\rho$ value (0.00) with the mental-emotional development of early childhood in the working area of Puskesmas Guntung Manggis. Conclusions: It is expected for the mothers to provide exclusive breastfeeding and change parenting to positive parenting to support optimal mental-emotional development of children.
\end{abstract}

Keywords: Breastfeeding, Parenting, Emotional Development

\section{INTRODUCTION}

Background Children are the future successors of the world. Therefore, every child has the right to a decent life. Every year there are 10 million babies born into the world and will develop into adults later. Many of them are denied rights in terms of love, nutrition, protection and security, as well as the need to grow and develop (Yulita, 2014).

Early childhood is a group of children who are in a unique process of growth and development (Muamanah, 2018). This period is the most appropriate time to lay the first and foremost foundation in developing various potentials and abilities of physical, cognitive, language, art, social emotional, spiritual, selfconcept, and independence (Muamanah, 2018).

Growth and development describe the quality of children (Dwiawati, 2016).
Development is the result of the interaction of the maturity of the central nervous system with certain organs it influences, for example the development of the neuromuscular system, speech, emotion and socialization. All of these functions play an important role in a complete human life (Ministry of Health, 2016).

Children's emotional development is a process of interaction and maturation of body organs including mental development and physiological and psychological behavior of children to control, process, and control emotions that are used to respond to the surrounding environment. Emotions play such an important role in life, it is important to know how the development and influence of emotions on personal and social adjustment (Dwiawati, 2016).

Mental health problems are common at a young age and begin to appear at a young age. One in ten children have serious mental health 
problems that can interfere with the function and participation of children in the home, school, and community environment (Indanah, 2019). It is estimated that the prevalence of emotional and behavioral problems in children is $20 \%$ (Dwiawati, 2016).

The socio-emotional development index of children aged 36-59 months in Indonesia is still below the average index of other countries (69.9\%). Compared to Thailand (79.4\%), Kazakhstan $(82.1 \%)$ and Vietnam $(91.2 \%)$ (RI Balitbangkes, 2018). Meanwhile, the socioemotional development index of children aged 3659 months in South Kalimantan is still below the national average index of $67.9 \%$. The socioemotional development index of children aged 3659 months in urban areas in South Kalimantan is also still below the average index of South Kalimantan (61.30\%) (RI Balitbangkes, 2018).

The process of child development does not only stop at an early age but continues into adulthood. Food (nutrition) has an important role in this process. Exclusive breastfeeding is an appropriate and reliable means in building the quality of human resources. Breast milk is the perfect food for baby's growth and development in the first 6 months (Marliana, 2017). Based on the 2018 Community Nutrition Improvement Program Indicator Performance Report, the coverage of exclusive breastfeeding at the Guntung Manggis Health Center is in 3 working areas of the Puskesmas with the lowest coverage of exclusive breastfeeding, namely (37.65)\% (Banjar District Health Office, 2018).

In addition to exclusive breastfeeding, parenting also affects the mental and emotional development of children. Parenting patterns in the family environment that are not good, such as punishing children by shouting and screaming will have an impact on children's behavior becoming negative and out of control. This has a negative impact on the emotional development of children (Muamanah, 2018). Family life is the first school for studying emotions. More than that, parents are emotional coaches for their children (Muamanah,
2018). The interaction of children and parents in early life is important as the basis for a child's emotional development, harsh parenting can increase the frequency of occurrence of behavioral disorders in children (Muamanah, 2018).

The purpose of this study is to provide additional insight to mothers about the benefits of exclusive breastfeeding and improvement of child care patterns so that children's mental and emotional development can run optimally. Based on the above background, this study was conducted to determine the relationship between exclusive breastfeeding and parenting with the mental and emotional development of early childhood in the working area of the Guntung Manggis Health Center in 2021.

\section{METHOD}

Research type and design This type of research is analytic observational by using a cross sectional design. The research was carried out in the working area of the Guntung Manggis Health Center in April 2021.

Population and sample the population in this study was early childhood (3-6 years) in the Guntung Manggis Working Area with a total of 1097 people and a sample of 92 children as part of the population. Materials and Tools The sampling technique used in this study was non-probability sampling with a simple random sampling method. Data collection techniques Primary data was obtained through interviews using questionnaires, secondary data obtained through archives and documents at the Guntung Manggis Health Center. Analysis Data analysis used Spearman Rank Correlation test with $95 \%$ confidence level and $=0.05$.

\section{RESULTS AND DISCUSSION}

\section{Bivariate Analysis}

The results of the cross tabulation in table 3 contain a description of each research variable in the early childhood group which has a category of normal and abnormal emotional mental development. 
Table 1. The Relationship of Exclusive Breastfeeding and Parenting Patterns with Mental Emotional Development of Early Childhood in the Working Area of the Guntung Manggis Health Center in 2021

\begin{tabular}{|c|c|c|c|c|c|c|c|}
\hline \multirow{2}{*}{\multicolumn{2}{|c|}{ Bivariate Analysis }} & \multicolumn{4}{|c|}{ Early Childhood Emotional Mental } & \multirow{2}{*}{\multicolumn{2}{|c|}{ Total }} \\
\hline & & \multicolumn{2}{|c|}{$\begin{array}{l}\text { Develop! } \\
\text { Normal }\end{array}$} & \multicolumn{2}{|c|}{$\begin{array}{l}\text { Mental } \\
\text { Abnormal }\end{array}$} & & \\
\hline & & $\mathbf{n}$ & $\%$ & $\mathbf{n}$ & $\%$ & $\mathbf{n}$ & $\%$ \\
\hline & Exclusive & 32 & 53,3 & 28 & 46,7 & 60 & 100 \\
\hline Ekscluvie & Not Exclusive & 4 & 12,5 & 28 & 87,5 & 32 & 100 \\
\hline \multirow[t]{3}{*}{ Bressfeeding } & Total & 36 & 39,1 & 56 & 60,9 & 92 & 100 \\
\hline & $\alpha=0,05$ & $p=0,000$ & \multicolumn{2}{|c|}{$\mathbf{r}_{\mathrm{s}}=\mathbf{0 , 3 9 8}$} & & & \\
\hline & Positive & 30 & 55,6 & 24 & 44,4 & 54 & 100 \\
\hline \multirow{3}{*}{ Parental } & Negative & 2 & 5,3 & 36 & 94,7 & 38 & 100 \\
\hline & Total & 32 & 34,8 & 60 & 65,2 & 92 & 100 \\
\hline & $\alpha=0,05$ & $p=0,000$ & \multicolumn{3}{|c|}{$\mathbf{r}_{\mathrm{s}}=\mathbf{0 , 5 2 0} * *$} & & \\
\hline
\end{tabular}

Based on table 1, the value $(\rho)=0.00$ and the correlation coefficient $(\mathrm{rs})=0.398$ which indicates the strength of the moderate relationship. From these results, it shows that $<(0.05)$ so that Ho is rejected which indicates a relationship between exclusive breastfeeding and the emotional mental development of early childhood in the working area of the Guntung Manggis Health Center in 2021 with a positive relationship direction.

Based on table 1, the value $(\rho)=0.00$ and the correlation coefficient $(\mathrm{rs})=0.520$ which indicates the strength of a strong relationship. From these results, it shows that $<(0.05)$ so that Ho is rejected, which indicates a relationship between parenting and mental emotional development of early childhood in the working area of the Guntung Manggis Health Center in 2021 with a positive relationship direction.

The results showed that there was a significant relationship between exclusive breastfeeding and the mental and emotional development of early childhood in the working area of the Guntung Manggis Health Center. The strength of the moderate relationship means that the variable of exclusive breastfeeding has a role of 0.398 on the mental and emotional development of children. The correlation relationship is positive, this shows a unidirectional relationship, namely the better exclusive breastfeeding, the better the mental emotional development. The results of this study are in line with the results of research conducted by Yuliani (2017) which states that exclusive breastfeeding has an effect on social development and mental emotional children (Sakinah et al, 2018).

The reason why even though most mothers have given exclusive breastfeeding, there are still many children's mental emotional development in the abnormal category due to the lack of support for other factors such as parenting and stimulation. Mothers do not apply positive parenting or are cared for by other family members. Stimulation can be done by mothers such as when breastfeeding. Mothers can chat with their babies, this can affect the baby's emotions. However, this is often not found for various reasons. What is happening the most now is the lack of interaction between parents and children because it is limited by smartphones and other technologies. This is a phenomenon that often occurs in the general public today (Tasnim, 2014). However, breast milk is still the best nutrition for babies because it contains all the nutrients that the baby's body needs for their growth and development.

Breastfeeding has an important role in the social and emotional development of children. Epidemiological studies conducted on a large group of exclusively breastfed children with a comparison group fed formula milk showed that children who were exclusively breastfed had good social adjustment, interpersonal relationships and social maturity (Tasnim, 2014). Lind et al (2014) also stated that children who were exclusively breastfed had fewer emotional problems than children who were not exclusively breastfed (Lind et al, 2014). 
There is a significant relationship between parenting patterns for the mental emotional development of early childhood in the working area of the Guntung Manggis Health Center and the strength of a strong relationship, meaning that the parenting style variable has a role of 0.520 on the mental development of early childhood. The correlation relationship is positive, this shows a unidirectional relationship, namely the better the parenting pattern, the better the mental emotional development. The results of this study are in line with research conducted by Putri (2019) which states that there is a relationship between parenting patterns and the level of emotional intelligence in preschool children (4-6 years) at Darma Wanita Teguhan Ngawi Kindergarten (Putri, 2019).

In this study, there are 2 types of parenting according to the theory proposed by Muchtar (2011) in Mukti (2017), namely about positive and negative parenting patterns. Positive parenting is parenting given by parents to children by fostering positive concepts and thoughts as well as selfrespect. Based on the results of the study, most mothers apply positive parenting patterns such as providing opportunities or training their children to express their feelings. Negative parenting is when parents often do negative things, such as hitting, ignoring, paying less attention, being unfair, never praising and so on (Mukti, 2017).

The reason why even though most mothers have implemented positive parenting patterns, there are still many children's mental emotional development in the abnormal category is the lack of support from other factors such as nutritional factors (ASI) and environmental factors (social/peers). Some children tend to choose to play alone / play gadgets compared to playing with their peers. With peers, children will provide mutual support to each other in dealing with stress and creating a pleasant atmosphere. Then, this situation can provide a "safe base" for further social learning (Maulah, 2020).

However, parenting styles from fathers and mothers have a real role in shaping children's social and emotional states. Excessive tolerance and excessive parenting from parents who are too harsh on children can hinder children's social emotional development (Nisa, 2019). All of the above factors must go well side by side so that the child's mental emotional development can run normally.

\section{CONCLUSION}

Based on the research that has been done, it can be concluded that most of the respondents in the working area of the Guntung Manggis Public Health Center have carried out exclusive breastfeeding, implemented positive parenting patterns and the mental emotional development of early childhood in the area included in the abnormal category. Then, it is known that there is a relationship between exclusive breastfeeding and parenting with the mental and emotional development of early childhood in the working area of the Guntung Manggis Health Center in 2021.

For further researchers, it is recommended to conduct research with different research designs such as case-control with more diverse variables such as chronic disease, socio-economic (income), parenting environment and other factors so that they can conclude what factors affect children's mental emotional development. early age. As for the parenting style variable, it can be developed with different types of parenting, for example democratic parenting.

Anknowledgement. The authors would like to thank the Head of the Guntung Manggis Health Center, the Director of the Banjarmasin Health Polytechnic, the Advisory Lecturers and all those involved in the implementation of this research.

\section{REFERENCES}

Yulita R. 2014. The Relationship of Parenting Patterns on Toddler Child Development at the East Cipatat Sakura Health Center. Thesis,

(http://repository.uinjkt.ac.id/dspace/bitstrea $\mathrm{m} / 123456789 / 25651 / 1 /$ Refi\%20Yulita\%

20-\%20fkik.pdf) accessed 07 July 2020 Quinn P, Yeagley D. 2005. Insulin regulation of PEPCK gene expression: a model for rapid and reversible modulation. Curr Drug Targets-Immune, Endocr Metab Disord 5[4]:423-437. PMID: 16375695.

Muamanah, Siti. 2018. The Influence of Parenting Parenting on the Social Emotional 
Development of Children Age 4-5 Years in Bandar Abung Village, Abung Surakarta District, Lambung Utara Regency. Thesis, (http://repository.radenintan.ac.id/5525).

Accessed on 07 July 2020

Dwiawati. 2016. The Relationship of Exclusive Breastfeeding with Emotional Development in Children aged 48 - 60 Months at the Borobudur Health Center, Magelang Regency 2016. Thesis, (http://eprints.poltekkesjogja.ac.id/1664/). Accessed 05 July 2020 .

Ministry of Health RI. 2016. Guidelines for the Implementation of Stimulation, Detection and Early Intervention of Child Development at the Primary Health Service Level. Directorate of Family Health, Jakarta: 3

Indanah and Yulisetyaningrum. 2019. Social Emotional Development of Preschool Age Children. Journal of Nursing and Midwifery 2019 Vol.10, No.1. Accessed 18 August 2020.

RI Balitbangkes. 2018. Basic Health Research (Riskesdas). Jakarta

Marliana. 2017. The Effect of Exclusive Breastfeeding on Infant Development in Kekait Village, Gunung Sari District. Prima Health Journal 2017 Vol.11, No.1 (Anzdoc). Accessed 05 July 2020

Banjar District Health Office. 2018. Banjar District Annual Profile Report.

Yuliani, Vini. 2019. The Effect of Exclusive Breastfeeding on Children's Social \& Mental Emotional Development. Literature Study, (https://www.researchgate.net/publication/3 30822201_PENGARUH_ASI_EKSKLUSI F_TERHADAP_PERKEMBANGAN_SOS IAL_MENTAL_EMOSIONAL_ANAK).
Accessed April 19, 2021.

Sakinah Nur, Ni Luh NA, I Made Krisna D. 2018. Differences in the Levels of Development of Exclusively and Non-Exclusively Breastfed Babies in the Padang Karambia Health Center Work Area South Payakumbuh District. Indonesian Physiotherapy Scientific Magazine [5] 3: 44-48.

Tasnim, S. 2014. Effect of Breast Feeding on Child Development: at Birth and Beyond. South East Asia Journal of Public Health. 2014;4[1]:4-8. Accessed April 19, 2021

Lind J N, Li R, Perrine C G. 2014. Breastfeeding and Later Psychosocial Development of Children at 6 Years of Age. American Academy of Pediatrics volume 134 supplements

Putri, Asri NA. 2019. The Relationship of Parenting Patterns to the Level of Emotional Intelligence of Preschool Age Children [4-6 Years Old] At Dharma Wanita Ngawi Kindergarten. Thesis, (http://repository.stikes-bhm.ac.id/ 637/1/1.pdf). Accessed on 20 July 2020

Mukti, B. 2017. Relationship between Young Mother Parenting and Development of Toddlers Age 12-36 Months in the Saptosari Gunung Kidul Community Health Center in 2017.

Thesis, (http://eprints.poltekkesjogja.ac.id/1553/). Accessed at 20 July 2020.

Maulah, R. 2020. The Influence of Peers on Early Childhood Social Emotional Development.

Nisa, Dessy. 2019. The Effect of Parenting Patterns in Shaping Early Childhood Emotional Social Behavior. Thesis, (http://eprints.walisongo.ac.id/9797) Accessed on 20 July 2021. 